\title{
The effect of the cytoplasms of Brassica napus and $B$. juncea on some characteristics of $B$. carinata, including flower morphology
}

\author{
Caitao Chang · Ryota Uesugi · Kana Hondo • \\ Fumika Kakihara $\cdot$ Masahiro Kato
}

Published online: 27 June 2007

(C) Springer Science+Business Media B.V. 2007

\section{Erratum to: Euphytica \\ DOI 10.1007/s10681-007-9424-4}

Due to an unfortunate misunderstanding, the first author's name appeared incorrectly in the original publication. The correct representation of the authors and their affiliations are listed above and below.

The online version of the original article can be found under doi: 10.1007/s10681-007-9424-4.

C. T. Chang $\cdot$ K. Hondo $\cdot$ F. Kakihara $\cdot$ M. Kato $(\square)$ Laboratory of Plant Breeding, Faculty of Agriculture, Ehime University, 3-5-7 Tarumi, Matsuyama 790-8566, Japan

e-mail: Kato@agr.ehime-u.ac.jp

R. Uesugi

Seinan Kaihatsu Company Ltd, 1-300-1,

Miyauchi Honai-cho, Ehime, Yawatahama-shi 796-0293, Japan 